\title{
Ambivalence in adulthood: Leaving the parental home
}

\author{
Ambivalência na adultez: a \\ saída da casa dos pais
}

\author{
Celia Regina HENRIQUES ${ }^{1}$ \\ Terezinha FÉRES-CARNEIRO' \\ Andrea Seixas MAGALHÃES
}

\begin{abstract}
The purpose of this study was to understand the articulation of dialogues during the emerging adult's leaving home process including the problematization and tensions involved. Semi-structured interviews were conducted with 10 middle-class young adults, aged 26 to 36, who still lived with their parents in the city of Rio de Janeiro, Brazil. Several categories emerged from the content analysis, among which three are presented in this article: apprehension concerning the relational space, agreements and negotiations, and the perceptions of leaving the parental home. It was verified that leaving the parental home is a dynamic process negotiated between family members. It became evident that the gains and losses from living together for a long period of time are part of an ambivalent relational environment. The time necessary for the development of parent-children relationship cannot be determined chronologically since it is the time necessary for the subjects to understand themselves at a relational level.
\end{abstract}

Keywords: Ambivalence; Family relations; Parent-child relation.

\section{Resumo}

Este estudo tem como objetivo compreender como se articulam os diálogos na saída de casa dos filhos adultos, desde a sua problematização até as tensões envolvidas. Realizou-se uma investigação baseada em entrevistas semiestruturadas com dez filhos adultos coabitantes com os pais, com idades entre 26 e 36 anos, cariocas de classe média. Da análise de conteúdo empreendida, emergiram diversas categorias, dentre as quais três são apresentadas neste estudo: apreensões sobre o espaço relacional, constituição de acordos e negociações e percepções sobre a saída da casa dos pais. Constatou-se que a saída da casa dos pais é um processo dinâmico, negociado entre os membros da família. Evidenciou-se que os ganhos e as perdas com a convivência prolongada fazem parte de um ambiente relacional ambivalente. Existe um tempo da relação pais-filhos não-cronológico, com a duração necessária para que os sujeitos possam compreender-se no âmbito relacional.

Palavras-chave: Ambivalência; Relações familiares; Relações pai-filho.

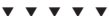

1 Pontifícia Universidade Católica do Rio de Janeiro, Centro de Teologia e Ciências Humanas, Departamento de Psicologia. R. Marquês de São Vicente, 225, Gávea, 22543-900, Rio de Janeiro, RJ, Brasil. Correspondência para/Correspondence to: C.R. HENRIQUES. E-mail: <celiahenriques@globo.com>.

Support: Fundação de Amparo à Pesquisa do Estado do Rio de Janeiro.
} 
Long-term family coexistence is currently a growing trend, and it is recognized as a social construction of contemporary Western society. We understand that such a phenomenon, experienced by parents and children living together, is established upon the combination of intrafamilial aspects, such as the ambivalence of feelings regarding homeleaving and loss of the roles earned or the extrafamilial roles in a social context marked by instability and doubts (Borges \& Magalhães, 2009; Gallagher, Féres-Carneiro, \& Henriques, 2013; Henriques, Jablonski, \& Féres-Carneiro, 2004; Vieira \& Rava, 2012).

Traditionally, the process of leaving home, as pointed out by Ariès (1978), is associated with the achievement of autonomy by the children in conjunction with a gesture of love toward the parents. Current cultural transformations, however, show the complexity of this family moment, considering the diversity of factors that compete to define this multidetermined event. Among these transformations, we highlight two important ones. The first one is related to changes in the workplace, which contribute to the extension of educational achievement aimed at improving people's position in the labor market (Almeida \& Magalhães, 2011). The second one is the weakening of affective relations which supports the postponement of marriage (Jablonski, 2010).

Accordingly, we begin to examine the topic of leaving the parental home. The action of leaving home, as observed by Ramos (2006), is based on family coexistence through dialogues and conversations that occur over time, establishing a negotiation process.

We understand that this negotiation space in the relationship is characterized by two relevant and inherent questions for the subjects. The first one is psychological time, marked by hesitation and indetermination (Gondar, 1995; Khel, 2009) that conflicts with the haste and restlessness of presentday life (Bauman, 2011; Maciel Junior, 2012). The second one is ambivalence that is present as a constitutive component of subjective processes within relations (Laplanche \& Pontalis, 2001), and therefore, they are important in family relations.
We acknowledge that the contemporary subject resents not being in agreement with oneself, with others, and with the world; such resentment is established based on the social and cultural conditions of our time (Maciel Junior, 2012). It is also known that this subject has difficulty in dealing with the pain related to the anticipation of grief, facing what he or she may lose (Freud, 1916/2009; Peres, 2011).

The purpose of this study was to explore the perceptions of grown children who still live with their parents concerning family coexistence and the process of leaving home. The leaving-home plans and arrangements including the problematization and tensions involved were analyzed.

\section{Family space: Strategies, perviousness, and negotiations}

In parent-child relationships, there is a wide variety of veiled permissions that are inscribed within the scope of the unsaid. By breaking their parents' rules, children show a confrontational attitude and seem to do it with the silent consent of their parents. Accordingly Henriques, Féres-Carneiro, and Ramos (2011) argue that parents and children recognize their limits: they examine, observe, and try to modify their initial relationship dynamics.

The steps taken by one of them indicate the path taken the by the other, and new rules may be established in this process. A back and forth movement is then established in the relationship dynamics, forming a game of constant reconstruction and unlimited movement. Leaving the parental home is therefore a process that is gradually established.

According to Foucault (1963/2009), analyzing the limit is to place oneself at the dividing line where power binds what is visible and utterable into a single layer. Maciel Junior (2012) added that the limit is the extreme portion of the boundaries of the game. The limit does not have a place of its own; it is established through an outline, in which there is a fragile point or "suture".

The limit is something that can always be surpassed. When there is uneasiness about something, it is always possible to look outward, 
into the distance, and discover doorways from one field to another. The limit of an experience allows an exit from something that makes transgression possible. Therefore, both limit and transgression can be understood as two sides of the same coin. The moment when a limit is reached, transgression occurs, and it is embodied by a new limit (Maciel Junior, 2012).

Parents allow breaking or extending the rules, revealing the perviousness of the relationship (Ramos, 2006). Relieved from the initial strictness, this concealing or hesitant attitude instigates the establishment of proper grounds for the rule breaking demanded by the children. In order to gain more space, children adopt different approaches and arguments seeking to expand their personal domains (Henriques et al., 2011). Accordingly, leaving the parental home is a process that takes place in an enabling environment. Implicitly, this process is a wordless agreement based on personal initiative and common revolving thoughts. Explicitly, it indicates the ability to transform parent-child relationships (Maunaye, 2003; Singly, 1996).

The parental home-leaving process is seen here as a possible and future outcome of a dynamic game that is lived within the relational space and situated in the microcosm of everyday life (Féres-Carneiro, Henriques, \& Jablonski, 2011). The leaving home process must be established with the contribution of every family member and depends on personal conditions and motivations. Leaving the parental home contrasts with the heated relationship break-up that is caused by being "thrown out" or leaving against the parents' will. From this perspective, a negotiated leaving home could be considered as an agreement resulting from daily negotiations and renegotiations. We understand that the waiting period is singular (i.e., living together is marked by small struggles and daily engagements that are necessary to guarantee the continuity of the process until the moment of leaving; Henriques et al., 2011).

\section{Waiting period}

Since the negotiation process is unlimited, it is continuous and is inserted into a logic about the future, i.e., something that will eventually occur. Family members negotiate and renegotiate. Thus, family members negotiate and renegotiate based on their own demands. However, it is important to highlight that this movement is not translated by ascending motion. We highlight that this process does not always moves forward. This recognition is related to a psychological time that cannot be measured. As Khel (2009) pointed out, "It is a time that depends on the other" (p.119). In other words, it is the time that pulsates between one's desires and another's demands. Therefore, we may say that a negotiated parental home-leaving process refers to relational time. It is the time necessary for the subjects to understand themselves within the extent of the relationship.

Gondar (1995) highlighted that we usually think of time as a universal category that is unambiguous in nature. In reality, however, we are always dealing with its particular and ambiguous apprehensions. This multiplicity does not resemble a single line or a smooth flow of time, but rather a tangled flow of time, marked by the folding and unfolding of several lines.

Analyzing the premises of the society of the spectacle (Debord, 1997) and liquid society (Bauman, 2011), we note that excitement, the compulsion for sensations, and the speed of information, among other factors, regulate today's life, which features a time denoted by haste (Khel, 2009). Dealing with this multitude of choices and possibilities imposed by a world of ephemeralities, the subject chooses not to choose (Maciel Junior, 2012), moved by the urgency of being able to participate. This nonchoosing subject, according to the author, is teased by worldly provocations, both fascinating and illusory. He or she narrows his or her horizon skewing the ability to think and assess because of the psychic effort that is needed to engage the issue and deal with this harassment.

We tend to think that choice presumes the rejection of the unchosen (i.e., it implies losing). In the study "On Transience", Freud (1916 [1915]) narrates his feelings in a walk through the countryside. He points out the sadness and skepticism of his companion, a poet, in a setting 
that is worthy of admiration, yet transitory. The author uses this metaphor to announce the anticipation of grief over the death of beauty. Freud highlights the limiting effects of time, associated with scarcity, fragility, and finitude noticing the subject's difficulty to let go of his objects and not relinquish what seems to be lost.

Peres (2011) updated Freud's study stating that the today's subject cannot experience grief or pain despite facing losses. The individual's feelings of inefficiency regarding what he or she cannot achieve and the dreams he or she cannot realize, reflect the civilization uneasiness. Life would be a struggle against displeasure and pain, and the individual should deal with the grief over his or her lack of achievements.

However, as reported in "On Transience":

Why it is that this detachment of libido from its objects should be such a painful process is a mystery to us and we have not hitherto been able to frame any hypothesis to account for it (Freud, 1916 [1915], p.250).

In this line of reasoning, it would seem that to relinquish - as done by the poet -, what seems precious and yet perishable, would be equivalent to not accepting the suffering that comes from loss.

It seems that besides choosing not to choose (i.e., not thinking about or assessing life), the subject does not accept the possibility of suffering. Such paroxysm, according to Maciel Junior (2012), would confirm the way in which modern-day individuals deny their singularity when facing contemporary cultural imperatives. We assume that the subjects of this study belong to this context. We also add that when dealing with the process of home leaving, parents and children may not identify the gains but only losses.

Among the considerations mentioned above, we also stress that the situation of parents and adult children living together is strongly marked by tension. Different worldviews and lifestyles, resulting from the experiences of each generation, can be encouraged and contribute to the emergence of conflict or the opposite, silence (i.e., nonconfrontation).
Conflict is a positive dimension, according to Simmel (1912/2003). The game of pros and cons that underlies conflict becomes a strategy, a tactical object, displaying both offensive and defensive movements that may exist within the relationship. When conflict arises within the family circle, parents and children put some of these strategies into play. The agreement or commitment that may come out of this negotiation will likely influence the reexamination of family rules (Henriques et al., 2011).

In such family interactions, discontentment or spirited and joyful exchanges are fully experienced and may disguise a conflicting circumstance. These two feelings constitute the opposing sides of conflict and mesh becoming a single unit, as reported by Simmel (1912/2003). According to Féres-Carneiro et al. (2011), it is quite common to encounter recollections of heated episodes that are retold in a spirited fashion. In these events, a new context is created, presenting a smoother and lighter reality.

\section{Method}

\section{Participants}

This study included 10 middle-class young adults (five men and five women), who still live with their parents (either married or divorced) in the city of Rio de Janeiro, Brazil. The participants were aged between 26 and 36 years, single, had college degree, and worked for a living.

\section{Instruments and Procedures}

This study was approved by the Research Ethics Committee of the Department of Psychology of Pontifícia Universidade Católica do Rio de Janeiro (Approval $n^{\circ}$ 010/2011).

To achieve the objective of this study, it was necessary to consider the hierarchical/egalitarian context as a privileged space of comprehension in this relational universe. 
Semi-structured interviews were conducted. Initially, two pilot interviews were conducted to define the main topics that would be used in the actual interviews. The main topics discussed with the interviewees were about their impressions of living with their parents, the conversations that were bound to create tension, and their perceptions of the separation from the parent-children relationship. The interviews were audiotaped. The audio recordings were transcribed to compose the corpus for content analysis (Blanchet \& Gotman, 2007) considering the objectives proposed.

\section{Results and Discussion}

To analyze the material obtained, each interview was evaluated with logical reference to the topics addressed. Based on the interviewees' statements, the following categories emerged: conceptions of the workplace, use of their salary, perceptions of love life, and perceptions of departure leaving the parental home. These categories are part of a broader investigation. In this paper, we chose to present the last three categories because they suit the objectives proposed better.

\section{Conceptions of relational space, subversions, and contradictions}

The coexistence of parents and adult children in a domestic setting led us to consider the relevance of small details in everyday family life. Based on our understanding, these details exposed the adjustments in the relationship to enable its continuity. These adjustments corresponded to the construction, reconstruction, or to breaking the family rules that are responsible for organizing the life of family members and concurrently legitimizing personal and collective interests. Among these interests, we highlight the validation of the children's autonomy and re-signification of the relationship as significant aspects of coexistence at this time in the life of people of two different generations (Ramos, 2006). We see family coexistence as a territory that is bounded by rules, agreements, negotiations, new agreements, and renegotiations of a continuous transformation process in this relational context.

The interviewees Pedro and Igor stated that life with their father or mother can be good and peaceful, but it is special strategies are needed to deal with the tensions related to living together. "Currently, living together is very good; we talk a lot, but I' $m$ rather impatient and have the tendency to get annoyed" (Pedro, 26 years old). "Living together is comfortable; talking little is essential to avoid tensions" (Igor, 26 years old).

The interviewees Joana and Carolina saw their relationship with their parents as very good, comforting, and a source of support and encouragement in their lives. "We have a super cool relationship, me and my mother" (Joana, 27 years old). "Living together is peaceful; I arrive late, leave early, but the good things about family are the benefits of being together, of helping each other out" (Carolina, 29 years old).

In contrast to these views, the interviewees Leticia and Fernanda defined their coexistence with their parents as a territory of tensions.

I've always wanted to have my own place; I interact in some decisions, but I don't feel this house as my own; it's theirs; on the other hand, I think that when I do leave I will miss this small space (Leticia, 36 years old).

There is a sense of defeat, among my circle of friends; some are celebrating the purchase of an apartment, changing their cars, marrying, and I am living in daddy's house, but it's ok; sometimes I feel that I will miss it very much when I leave. But there is stress (Fernanda, 34 years old).

These statements highlight views of coexistence that oscillate from perspectives of support and assistance to tension and discomfort. We understand that both generations in question enjoy the privilege of interacting under the horizontal premises of interpersonal relationships, marked by the notions of equality and mutuality, according to Vieira and Rava (2012). However, as stated by Simmel (1912/2003), conflict is an integral 
part of living; there is no life without conflict. The statements made by Pedro, Igor, Leticia, and Fernanda support these views and lead to the understanding that there is a place for ambivalence.

Conflicts arise from stressful situations, but they seem to be neutralized by a certain adjustment or compliance to the rules and boundaries established since they are part of a non-hierarchical relationship. We may consider it as a coexistence characterized by small daily dilemmas with intensified or defused that comprise the relational environment that are part of a scenario that enables the continuity of the family status (Henriques et al., 2011).

One of the interviewees, Fernanda, used strategies, such as provocation, to undermine her father's control. Using her experience in this relationship she is aware that every time the situation repeats itself, it loses some of its original power; it is like "mining" an area of conflict; "If I'm watching television, he arrives, grabs the remote and switches the channel; he doesn't like anything that I watch. I sit on his chair; I think that this makes him infuriated, but he's doing this less now" (Fernanda, 34 years old).

We highlight the importance of the violating what was established as an intrinsic part of this continuous transformation process (Foucault, 1963/ 2009; Maciel Junior, 2012). By sitting on her father's chair, Fernanda incites him to regain control of the situation. By using an object that is closer to him (the remote control) the father assumes a dominant position, and the argument begins. Every time this situation repeats, it seems to undergo small changes that are maintained and help her to establish a sense of authority or control.

The significant aspects of this intergenerational coexistence are the validation of the children's autonomy and re-signification of the relationship (Ramos, 2006). Fernanda breaks the house rules by developing dynamic ways of interaction; by doing this, she gains more space in the relationship. Similarly to Fernanda, Carolina breaks the rules of coexistence with her mother. "Sometimes she [mother] asks me to put my dirty clothes in the 10 laundry basket; I linger, I stall, then she can't stand it and does it for me. I think she tries and thinks: one day she will do it" (Carolina, 29 years old).

The acknowledgement that the household space belongs to the parents seems to be sufficient for the rules to be accepted, thus avoiding relationship conflicts. However, this acceptance does not mean the children have to be silent; it does not deny their right to express discomfort when facing certain parental impositions. According to Ramos (2006), when adult children are granted equal rights, parental rules are not as strict anymore. We believe that Carolina's stalling is related to an experimental attitude concerning her routine by going beyond her mother's established boundaries, daring to slightly break the rules, expanding the space.

Marcelo and his parents have a relationship based on irony, playfulness, and mockery. The use of irony is also a kind of indirect and non-explicit communication, which may play the role of protecting the relationship from the possibility of conflict (Kaufmann, 2007). It allows dialogues without the risk of conflicts and reflects annoyance and discomfort. "It's a quarrelsome way of being; I pick on my mother more, she gets mad; with my father I do it as well, he accepts the game and gets into it" (Marcelo, 29 years old).

Leticia says that she cannot be assertive and firm in daily disagreements with her parents, so she prefers to speak her mind by joking, smiling, and covering her uneasiness. The use of irony and playfulness conceals the seriousness of the circumstance, masking the confrontational intention. Leticia seems to use this form of communication to lessen a conflict that may arise from interaction. The communication objectives are reached through irony and playfulness, indicating the power that this type of language holds, especially in specific interaction situations.

When I arrive home tired, he [father] tries to get hold of me to solve his computerrelated problems; there is this dialogue: father, you know that I'm tired now; I may change it a little, in a playful tone: hey, dad, your little girl is very tired, I really wanted some juice (Leticia, 36 years old). 
We believe that this communication style, which is gentle and tactful, allows for easier enunciation. Nowadays, it seems to be preferable to shift direction and use a more indirect form of communication. The contemporary subject is intolerant to discomfort during coexistence (Peres, 2011). We highlight that these paths lead to what Simmel (1912/2003) said about the importance of conflict in interactions.

Five interviewees stated that the repeating the same conversation over and over causes discomfort and tension during coexistence. Kaufmann (2007) proposed that the repetitive routine seeks to diminish or defuse conflicts. Accordingly, repetition would be ritualized speech, which at the same time it reminds subjects of the conflict it tries to reduce it. Repetition equally shows the ability to emphasize or stress a conflict.

The interviewee Igor stated that his mother does not listen to him:

She tries to give me advice on studying for a (governmental) job examination; she suggests some things, but it's got nothing to do with anything; I told her that she didn't understand, but she said the same thing the next day; she repeated it and repeats it again (Igor, 26 years old).

Bruna, another interviewee, noticed that her mother repeats the same conversational pattern:

She begins to bother me, to pick on me regarding a certain subject; I tell her I heard her and she repeats it; her opinion doesn't change; she tries to convince me and doesn't give up until I pretend to agree (Bruna, 32 years old).

The conversation only ends when Bruna pretends to agree with her mother's arguments, which is a strategy to stop her from repeating again - a tactic to avoid explicit confrontation. In Bruna's speech, we notice impotence and acquiescence. According to the daughter, the fact that the mother gives her opinions over and over again indicates she does not recognize the other, does not listen nor see the other; in short, it is a speech to vent her feelings, as stressed by Kaufmann (1992).
We observed ambiguity in some interviewees' statements that defined the coexistence with parents as peaceful, whereas, at the same time, they defined it as repetitive, bothersome, and uncomfortable. These statements reveal hesitant and contradictory speech. The understanding of this contradiction does not seem clear to them.

It's complicated to coexist; there are lots of differences, but what are we to do? (Joana, 27 years old).

I'm laid back; I try to be easygoing, but it's not always possible (Igor, 26 years old).

It's cool, but I get mad a lot every day (Marcelo, 29 years old).

All in all, coexistence is good, but I hide my credit card bills in order to avoid stress (Daniel, 27 years old).

It's ok, but it's not; that's difficult; sometimes I don't know how to react (Leticia, 36 years old).

Since ambivalence is an integral part of the subjects (Laplanche \& Pontalis, 2001) and is inherent to family relations, we can say that the interviewees do not see this dimension in their lives. They may simply avoid reflecting upon something that does not make immediate sense to them. This way of thinking is aligned to what Henriques et al. (2011) stressed about the contradiction present in relationships between parents and adult children who live together. In this coexistence, a certain degree of ambivalence affects the predictability of actions and indicates the emotional exhaustion due to the situations faced.

On the other hand, it also enables the contribution of the non-nomination and nonclassification of what is already known, allowing expanded personal domains. If the subjects' understanding of the ambivalence may lead to coexistence with their parents, urging an increase in the limits or breaking the agreements made, the lack of understanding may indicate an environment that is marked by disorientation, tension, and discomfort. 


\section{Articulating the parental home-leaving process}

Some interviewees did not have a winning perspective, which could help them see the coexistence contradictions in as something that is inherent and transitory. Others, however, seem to realize and have a winning perspective. We note that these apprehensions are in agreement with the premises of contemporary culture, which acknowledges pleasure and gain (Debord, 1997; Bauman, 2011) and conceal losses (Peres, 2011; Maciel Junior, 2012).

Leticia and Marcelo mentioned the difficulty to think, assess, and choose. According to Maciel Junior (2012), the subject may choose not to choose due to intense, worldly provocations and psychic tensions in which he or she must engage to respond to these provocations. "I'll have to live elsewhere; that's sad; I don't like thinking about it" (Leticia, 36 years old). "I know that someday I'll have to leave, I'll have to face that" (Marcelo, 29 years old). Not choosing may indicate that these subjects - as well as the kangaroo generation to which they belong (Gallagher et al., 2013) -, choose to avoid difficult situations and experiences that may cause discomfort and.

We also observe today that pain and grief are not accepted today like they used to be in more traditional times (Peres, 2011). The contemporary subject does not accept suffering; he or she submits him/herself to the modern cultural premises that one must always win. Words such as "loss," "death," and "sadness" indicate the subject's difficulty letting go of his or her material posessions without giving up what seems to be lost (Freud, 1916[1915]). We understand that while planning the process of home leaving, both Marcelo and Leticia were unable to see gain, only loss.

Carolina and Gustavo, however, seemed to acknowledge the possibilities of gains in this relational environment:

I'm cool here because I think I can choose; if I get involved with someone and it doesn't work out, I don't need to think the world is over; I have time to meet someone else and make it work, then marry, build a family 12 (Carolina, 29 years old).
I want to buy an apartment with my girlfriend in the neighborhood where I now live and marry. l'll miss the condo, that has everything, but l'll gain in freedom; I'll decorate it my way; I don't like my mom's style; I didn't choose anything here (Gustavo, 29 years old).

These two interviewees demonstrate that parental coexistence may be a period that consists of waiting for better times, when the achievement of life projects may be possible. The perceived gain is associated with the choice of a more long-term family coexistence, even if it involves tension and disorientation, as a necessary means to achieve futures plans (Gallagher et al., 2013).

The negotiation process (i.e., the construction and reconstruction of agreements; Ramos, 2006) defines the family environment as a flexible and pervious space. Advances and retreats of a relationship dynamics indicate a game of continuous reconstruction.

According to Gustavo and Bruna, their mothers try to speed up the process of leaving home.

I won't leave home to have a rough time; I'll only leave when I'm capable; with two incomes it will be doable; I wouldn't live by myself; I tell my mother this; she replies, she asks me if it will take long [laughter] (Gustavo, 29 years old).

I want to live with my boyfriend, but he's too laid back; I'm hanging around here; my relationship with her [mother] is good, but she reminds me I'm getting older [laughter] and she tells me to pressure him a little (Bruna, 32 years old).

The thought about leaving home is constructed in a dynamic way, establishing itself as an inter-game, in which the articulations are captured to formalize the process of leaving home. Joana and Marcelo's statements reveal how adult children subvert the relationship dimension with the purpose of preparing their parents for their leaving.

I think about working abroad, but I don't say anything; I casually mention things like 'don't worry about me' and wait for her 
reaction; she looks kind of doubtful and I switch subjects (Joana, 27 years old).

I'm a freelance professional; I tell them [father and mother], but they don't understand my points of view, but we talk about investments, rent. They talk, I answer, it's like that (Marcelo, 29 years old).

The choice of keep leaving together - despite knowing that they can have a separate home-, seems to be articulated in coexistence. This daily articulation enables family members to reconcile the sense of belonging while maintaining their own singularity (Henriques et al., 2011).

The following statements show situations of uncertainty, vagueness, and indetermination in the parents' home a sign of a waiting period for moving out. This period of time lived has nothing to do with cronus according to Gondar (1995). It is a personal experience since in our unconscious tells we are immortal. We consider that the same subject may experience different time overlaps and edifferent timing to deal with them. This multiple perspective enables a strategic assessment of the young adult who waits and hesitates.

I crave for a place of my own, but I need time (Bruna, 32 years old).

In two years time, I can think about leaving; I'll wait (Joana, 27 years old).

I'm on the edge; someday it will happen; I don't know for sure when (Igor, 26 years old).

I'm dealing with it; I have a feeling that I'm late for stuff (Marcelo, 29 years old).

I'll wait a couple of years; if it gets complicated, I'll leave, but I think it's too far away (Daniel, 27 years old).

We believe that the interviewees used expressions such as "in two years" time", "if it gets complicated, I'll leave", and "someday it will happen" to give meaning to the time dimension in the construction of the parental home-leaving process. These definitions seem to indicate a perception of coexistence marked by an idea of separating the parent-children relationship. According to Khel (2009), time is psychological; it cannot be "measured". Rushing things up - a characteristic of today's reality - goes against the time needed by the subject to understand something.

\section{Final Considerations}

The interviewees' statements reveal a perception of coexistence marked by ambiguities. At the same time, they describe it as peaceful although they define it as repetitive, uneasy, and uncomfortable. Ambivalence affects the predictability of actions and indicates the emotional exhaustion due to the situations faced in the relationship. On the other hand, it enables to experience what has not yet been experienced, allowing and instigating extension of boundaries or limits.

The lack of understanding of this process may indicate an environment of disorientation, tension, and discomfort. The gains and losses of long-term family coexistence are felt and expressed, becoming an integral part of an ambivalent relational environment.

The thought about leaving the parental home is a dynamic process, as observed in the interviewees' statements. It is an inter-game, in which the articulations are captured to formalize the process of leaving home. Considering the negotiation process (i.e., the construction and reconstruction of agreements), family environment can be defined as a flexible and pervious space. Every member in the relationship recognizes their limits and the steps taken by one of them indicate the path taken the by the other. Through this process, the space is constantly changing and facilitating the problematization of moving out from the parental home the departure.

Therefore, we may say that leaving the parental home occurs within the relationship time, which lasts until the subjects can understand themselves at a relational level. It can be seen that there is perception of the time, which lasts to reduces the indetermination of the moment that is being currently lived.

However, since contemporary temporality is based on haste, it affects the time of understanding 
and contributes to the establishment of a environment of confusion and disorientation. Thus, parental home-leaving process is negotiated by children and parents as a game of possible advances and retreats, lived within the space of the relationship and situated in the microcosm of everyday life.

\section{Contributors}

C.R. HENRIQUES participated on the conception, gathering of information, data analysis and the composition of this article. T. FÉRES-CARNEIRO collaborated on the data analysis, the composition and revision of this article and A.S. MAGALHÃES collaborated on the composition and revision of this article.

\section{References}

Almeida, M. E. G. G., \& Magalhães, A. S. (2011). Escolha profissional na contemporaneidade. Revista Brasileira de Orientação Profissional, 12(2), 205-214. Recuperado em abril 07, 2014, de http://pepsic.bvsalud. org/scielo

Ariès, P. (1978). História social da criança e da família. Rio de Janeiro: Guanabara.

Bauman, Z. (2011). A ética é possivel num mundo de consumidores? Rio de Janeiro: Zahar.

Blanchet, A., \& Gotman, A. (2007). L'Enquête et ses méthodes, I' entretien. Paris: Armand Colin.

Borges, C. C., \& Magalhães, A. S. (2009). Transição para a vida adulta: autonomia e dependência na família. Psico, 40(1), 42-49.

Debord, G. (1997). A sociedade do espetáculo. Rio de Janeiro: Contraponto.

Féres-Carneiro, T., Henriques, C. R., \& Jablonski, B. (2011). Um jogo interativo: a relação entre pais e filhos adultos no cotidiano familiar contemporâneo. Psico, 42(2), 236-245.

Foucault, M. (2009). Prefácio à transgressão. In Focault, M. Estética: literatura e pintura, música e cinema (Coleção Ditos e escritos, Vol.3, pp.28-46). Rio de Janeiro: Forense Universitária. (Originalmente publicado em 1963).

Freud, S. (2009). A transitoriedade. In S. Freud. Obras completas (Vol.12). São Paulo: Companhia das Letras. (Originalmente publicado em 1916).

Freud, S. (1916 [1915]). On Transience. In Freud, S. The standard edition of the complete psychological works of Sigmund Freud (Vol.XIV, 1914-1916, pp.303-307).
Gallagher, I. M., Féres-Carneiro, T., \& Henriques, C. R. (2013). Planos para o futuro: percepções de filhos adultos coabitantes com os pais. Revista da SPAGESP, 14(2), 4-18. Recuperado em abril 20, 2014 de http:// pepsic.bvsalud.org/scielo.php?script=sci_arttext\& pid $=$ S1677-29702013000200002

Gondar, J. (1995). Os tempos de Freud. Rio de Janeiro: Revinter.

Henriques, C. R., Féres-Carneiro, T., \& Ramos, E. (2011). Ajustes entre pais e filhos adultos coabitantes: limite e transgressão. Psicologia em Estudo, 16(4), 531-539. Recuperado em junho 1, 2014, de http://www. scielo.br/scielo.php?pid=\$1413-3722011000400004 \&script=sci_arttext

Henriques, C. R., Jablonski, B., \& Féres-Carneiro, T. (2004). A geração canguru: algumas questões sobre o prolongamento da convivência familiar. Psico, 35(2), 109-226.

Jablonski, B. (2010). A divisão de tarefas domésticas entre homens e mulheres no cotidiano do casamento. Psicologia: Ciência e Profissão, 30(2), 262-275.

Kaufmann, J. C. (1992). La Trame Conjugale, analyse du couple par son linge. Paris: Nathan.

Kaufmann, J. C. (2007). L’ Entretien Compréhensif. Paris: Armand Colin.

Khel, M. R. (2009). O Tempo e o cão, a atualidade das depressões. São Paulo: Boitempo.

Laplanche, J., \& Pontalis, J. B. (2001). Vocabulário da psicanálise. São Paulo: Martins Fontes.

Maciel Júnior, A. (2012). Pensar na era do excesso. Cadernos de Psicanálise - SPCRJ, 28(31), 215-235.

Maunaye, E. (2003). Les jeunes adultes et leurs parents, autonomie, liens familiaux et modes de vie. Culture et Societé. Québec: Université Laval.

Peres, U. T. (2011). Uma ferida a sangrar-Ihe a alma. In S. Freud. Luto e melancolia. São Paulo: Cosac Naify.

Ramos, E. (2006). As negociações no espaço doméstico. In M. L. Barros (Org.), Família e gerações. Rio de Janeiro: FGV.

Simmel, G. (2003). Le Conflit. Dijon-quetigny: Circé. 2003. (Publié à I'origine en 1912).

Singly, F. (1996). Le Soi, le couple et la famille. Paris: Nathan.

Vieira, A. C. S., \& Rava, P. G. S. (2012) Ninho cheio, perspectivas de pais e filhos. Psicologia: Teoria e Prática, 14(1), 84-96. Recuperado em março 20, 2014, de http://editorarevistas.mackenzie.br/index.php/ptp/ article/viewFile/2308/3366

Received: September 5, 2014

Final version: January 26, 2015

Approved: March 26, 2015 